\title{
Indflydelse i vidensarbejdet - kan man få for meget af det gode?
}

\author{
Sørensen, Ole Henning; Buch, Anders; Christensen, Peter Holdt; Andersen, Vibeke
}

Published in:

Tidsskrift for Arbejdsliv

Publication date:

2007

Document Version

Early version, also known as pre-print

Link back to DTU Orbit

Citation (APA):

Sørensen, O. H., Buch, A., Christensen, P. H., \& Andersen, V. (2007). Indflydelse i vidensarbejdet - kan man få for meget af det gode? Tidsskrift for Arbejdsliv, 9(2), 38-54.

\section{General rights}

Copyright and moral rights for the publications made accessible in the public portal are retained by the authors and/or other copyright owners and it is a condition of accessing publications that users recognise and abide by the legal requirements associated with these rights.

- Users may download and print one copy of any publication from the public portal for the purpose of private study or research.

- You may not further distribute the material or use it for any profit-making activity or commercial gain

- You may freely distribute the URL identifying the publication in the public portal

If you believe that this document breaches copyright please contact us providing details, and we will remove access to the work immediately and investigate your claim. 


\title{
Indflydelse i vidensarbejdet - kan man få for meget af det gode?
}

\author{
Ole Henning Sørensen, Anders Buch, Peter Holdt Christensen \& Vibeke Andersen
}

Det rapporteres stadig oftere, at veluddannede lider af alvorlig stress. Dette forekommer paradoksalt, fordi de ifølge den meget benyttede krav-kontrolmodel ikke burde befinde sig i risikozonen. De har udviklende job med høj grad af indflydelse. Det tyder på, at stressforståelsen og krav-kontrolmodellen trænger til at blive diskuteret. Artiklen viser gennem en historisk beskrivelse, at stressbegrebet er til stadig genfortolkning, og at dette ikke alene skyldes akademisk definitionsarbejde. Stressbegrebet afspejler mange forskellige samfundsmæssige interesser, og de konkrete modeller og stressforståelser har stor betydning for, hvilke jobgrupper der betragtes som udsatte, og for hvilke forbyggende tiltag som kan anbefales. Artiklen argumenterer specielt for, at der er problemer med forståelsen af indflydelse i krav-kontrolmodellen, idet den leder til uhensigtsmæssige anbefalinger til forbedringer af vidensarbejdet.

/ Veluddannede segner af stress", "Forsikrings-
selskaber slår alarm: Danskere bliver alvorligt syge af stress på jobbet. Det er i stigende grad yngre veluddannede lønmodtagere, der voelter omkuld" (Politikens forside d. 2. oktober 2006). Denne form for overskrifter har fyldt dagbladene gennem det sidste års tid, og en række fagforbund har foretaget stressundersøgelser blandt deres medlemmer. En undersøgelse foretaget af Ingeniøren (Ingeniøren 2.10.2006) beskriver eksempelvis, at hver anden ingeniør generelt føler sig stresset, og hver tredje har mindst én gang om ugen besvær med at koncentrere sig, tænke klart og tage beslutninger. DJØF's stressundersøgelse fra 2005 bekræfter denne undersøgelses resultater og viser, at stress fører til sygefravær på medlemmernes arbejdspladser.

Stressfænomenet er tilsyneladende blevet et udbredt fænomen hos veluddannede på det danske arbejdsmarked - et fænomen, som i stigende grad er kommet i offentlighe- dens søgelys, og som diskuteres flittigt i dagspressen. Men er det rigtigt, at de veluddannede lider af stress? De veluddannede er - alt andet lige - en privilegeret gruppe på arbejdsmarkedet, der - i sammenligning med andre grupper på arbejdsmarkedet - har nogle af de bedste arbejdsvilkår. Arbejdet betragtes både fagligt og personligt som godt og udviklende. Det er typisk karakteriseret ved høj grad af selvbestemmelse, indflydelse, belønning, støtte, m.m. Dette er faktorer, som vurderes at være af væsentlig betydning for et godt psykisk arbejdsmiljø i en af de mest dominerende modeller til diskussion af stress og psykisk arbejdsmiljø - krav-kontrolmodellen (Karasek \& Theorell 1990) og i opsummeringen fra Det Nationale Forskningscenter for Arbejdsmiljø (NFA) af de vigtige faktorer i et godt psykisk arbejdsmiljø, "de seks guldkorn" (Kristensen 2006).

En ny undersøgelse fra NFA (offentliggjort d. 15.2.2007) viser, at de mest stresse- 
de arbejdsgrupper i dagens Danmark tæller jobs med ensidigt arbejde og lav indflydelse (eksempelvis tapperiarbejdere og pakkere), mens $\mathrm{fx}$ akademikere og offentligt ansatte chefer ikke på tilsvarende niveau er plaget af stress. Undersøgelsen begrunder dette forhold $i$, at de veluddannede grupper ofte har større indflydelse på deres arbejde. Det er velkendt og alment anerkendt - som det også kommer til udtryk i ovennævnte undersøgelse fra NFA - at stress kan forekomme i forbindelse med stærkt belastende arbejde præget af manglende indflydelse, høj grad af kontrol, stærkt hierarkiske organisationsformer med videre.

Det er imidlertid et relativt nyt og omstridt fokus, at stress skulle være et stort problem hos veluddannede. Nogle forskere antyder da også, at dette fokus på de veluddannede grupper primært skyldes, at de, som skriver om problemet, selv oplever, at de bliver ramt af stress (journalister og forskere), men at det ikke er et særligt problem for denne gruppe (Bason m.fl. 2003). Der er således et tilsyneladende paradoks mellem fagforeningernes undersøgelser og den stressforskning, som har baggrund i kravkontrolmodellen. Det er dette paradoks, som udforskes i denne artikel.

Artiklen er bygget op således, at vi først kort gør rede for, hvad der kendetegner den gruppe af veluddannede vidensarbejdere, som artiklen beskæftiger sig med. Vi tager i artiklen et videnssociologisk udgangspunkt, hvor vi benytter en historisk gennemgang til at anskueliggøre, at ubestemtheden ved stressbegrebet er et udtryk for en fortløbende interessebestemt (re)konstruktionsproces. I artiklen har vi valgt at fokusere på stressbegrebet, selvom begrebet vidensarbejderen kunne fortjene en lignende diskussion. Vi giver i et historisk tilbageblik en beskrivelse af stressbegrebets fødsel i 1930'erne og udvikling frem til 1970'erne. Dette historiske rids viser, at stressbegrebets konstruktion og betydning kan relateres til bredere samfundsmæssige processer, hvor et heterogent felt af interessenter har giort deres indflydelse og interesser gældende i skabelsen af et nutidigt stressbegreb.

Denne (re)konstruktionsproces er imidlertid ikke nået til vejs ende. Stressbegrebet bliver til stadighed problematiseret, og der findes fortsat forskellige og divergerende stressforståelser i omløb i såvel den akademiske som den bredere samfundsmæssige debat. Vi fører derfor diskussion videre til at diskutere den meget udbredte krav-kontrolmodel i forhold til vidensarbejdet med henblik på at undersøge, om denne forståelse kan rumme de vilkår, som gør sig gældende i vidensarbejdet.

\section{Vidensarbejderkonstruktionen}

Inden vi diskuterer stress yderligere, vil vi kort gøre rede for, hvad vi her forstår ved vidensarbejde, og hvilke grupper vidensarbejdere vi fokuserer på. Italesættelsen af akademiske grupper som en voksende og specielt vigtig (og privilegeret) vidensarbejdergruppe i det såkaldte videns- eller informationssamfund har taget fart fra starten af 1990'erne (Castells 1996; Drucker 1993; Kelloway \& Barling 2000; Reich 1992). Der hersker dog ikke enighed om, hvad man skal forstå ved 'vidensarbejde' som begreb. Dette begreb er - på samme måde som stressbegrebet - underkastet en konstruktionsproces, hvor forskellige aktører - både i akademiske og bredere kredse - forsøger at afgrænse og klassificere fænomenet. Vidensarbejde og vidensarbejdere er således blevet beskrevet ud fra en række forskellige - og ikke indbyrdes afhængige - dimensioner som $\mathrm{fx}$ deres uddannelsesmæssige baggrund (Starbuck 1992), dybe ekspertise (Leonard \& Swap 2005), evnen til at kunne leve af at tænke (Davenport 2005) og deres evne til at tænke 
kreativt og dermed skabe nye ideer og innovation (Nonaka \& Takeuchi 1995).

Selvom der således ikke er enighed om, hvad en vidensarbejder er, er der en tendens til at betragte vidensarbejde som aktiviteter, der i højere grad fokuserer på kreativitet og samarbejde frem for på rutinepræget og individuelt arbejde. Vidensarbejdere er for eksempel blevet beskrevet som individer, der arbejder mere med hovedet end med hænderne (DeFillippi m.fl. 2005), og hvor vidensarbejdets karakter ikke programmerer vidensarbejderen, men tværtimod stiller krav om refleksivitet, kreativitet og fortolkning (Drucker 1999). Derudover er vidensarbejdere også blevet beskrevet som individer, der ikke alene har megen viden, men som også i høj grad er i stand til hurtigt at tilegne sig ny viden - det er således vidensarbejderens evne til at suge viden til sig, som gør det muligt at være både kreativ, analytisk og fortolkende (Sennett 2003). Selv om man kan mene, at både bonden og den faglærte industriarbejder også er vidensarbejdere, så er den type vidensarbejdere, vi diskuterer i denne artikel, begrænset til grupper såsom akademikere, ingeniører, arkitekter, designere, journalister og lignende.

I et stereotypt billede beskæftiger denne type vidensarbejdere sig kun med de kreative, udfordrende og spændende opgaver - men vidensarbejde er også en mere rutinepræget aktivitet. Vidensarbejderens autonomi og indflydelse på sit arbejde kan variere $\mathrm{i}$ forhold til arbejdets konkrete karakter og beskaffenhed og de organisatoriske rammer for arbejdet. Vidensarbejderens potentielle kontrol over sine opgaver og sine handlinger i løbet af arbejdsdagen vil således være stigende i takt med, at vidensarbejdere bevæger sig i retning af det mere kreative arbejde eller indtager rollen som ekspert (Davenport 2005).

Men selvom vidensarbejderens indflydelse på sit arbejde er en mere sammensat stør- relse end det populære billede lader vide, så er der ingen tvivl om, at vidensarbejdere har større indflydelse og variation i arbejdet - qua deres ekspertise og faglige autoritet end andre grupper på arbejdsmarkedet. Som forfatterne bag krav-kontrolmodellen fremhæver, så forøger udviklingen af færdigheder arbejdernes muligheder for at få eller at tiltage sig indflydelse (Karasek \& Theorell 1990). Ved en stigende indholdsmæssig kompleksitet i vidensarbejdet vil mere hierarkiske og autoritære ledelsesformer vise sig utilstrækkelige. Selvledelse er derfor en ofte anvendt ledelsesform i forhold til vidensarbejdere (Bovbjerg 2001; Bovbjerg 2003). Men der ses også ledelsesmæssige modtræk, for eksempel i form af standardisering af opgaver og metoder (Karreman m.fl. 2002; Nielsen \& Andersen 2004).

Overordnet set har vidensarbejderne forholdsvis stor indflydelse på struktureringen af arbejdsdagen, opgaver og metoder set i forhold til industriarbejdere. Oplæringstiden og cyklustiden for rutineprægede opgaver for vidensarbejdere måles ikke i minutter og sekunder, men i timer, dage, uger eller måneder. Ellers ville det næppe være meningsfyldt for ledelsen at investere i så relativt dyr arbejdskraft. Gruppen af vidensarbejdere har en interesse $i$, at billedet af det kreative og komplekse vidensarbejdet opretholdes, da det er medvirkende til at fastholde en privilegeret position på arbejdsmarkedet. Samtidig er der hos for eksempel fagforeningerne en interesse $i$ at fremhæve de vilkår, som er belastende. Med reference til arbejdsmiljøforskningen nævnes specielt høje (uendelige) krav i form af en potentielt endeløs række af relativt komplicerede opgaver, intensivt arbejde, rollekonflikter og uforudsigelighed i arbejdet (Allvin m.fl. 2006; Bason m.fl. 2003; Ipsen 2007; NFA 2006). Belastningerne italesættes ofte som groenseløst arbejde med familie/arbejdslivskonflikter (Albertsen m.fl. 2007; Allvin m.fl. 
2006; NFA 2006). Derudover er der stigende fokus på de negative konsekvenser af nye involverende ledelsesformers konsekvenser (Bovbjerg 2003; Tynell 2002).

Spørgsmålet er, som antydet i indledningen, om stress således er blevet et vilkår i det gode moderne arbejdsliv? (Dalsgaard 2006). Eller om vidensarbejdernes ressourcer og gode arbejdsforhold - for eksempel i form af høj indflydelse - burde modvirke udviklingen af stress, jævnfør krav-kontrolmodellen (Karasek \& Theorell 1990). Vi vil derfor i det efterfølgende undersøge, hvordan stressbegrebet har udviklet sig, og dernæst se nærmere på krav-kontrolmodellen.

\section{Stress som historisk forhandlingsarena}

Direktør Palle Ørbæk fra Det Nationale Forskningscenter for Arbejdsmiljø advarer $i$ et interview (BT 22.1.2007) mod at misbruge stressbegrebet:

"Stress er blevet et modeord, der bliver brugt
i floeng.[...] Når fagforeningerne siger, at
halvdelen af deres medlemmer er stressede,
så holder det ikke vand.[...] Det er simpelt-
hen ikke rigtigt. Så blander man begreberne
sammen og har givetvis spurgt på en måde,
der gør tallet større end nødvendigt. Hvis
man spørger: „Føler du dig stresset ", så vil
en raekke svare ja, fordi de svarer ja til, at de
føler sig pressede, oplever mange forandrin-
ger, er travle, har mange arbejdsopgaver og
mange private krav at leve op til. Men det
betyder ikke nødvendigvis, at de har stress $i$
ordets egentlige betydning."

Dermed antyder Palle Ørbæk, at der er en egentlig betydning af stress. Og det fremgår tydeligt, at der er delte meninger om, hvem der $i$ virkeligheden er stressramte, og hvad man egentlig skal forstå ved stress. Selvom - eller måske på grund af - at begrebet i løbet af de seneste årtier har vundet stor udbredelse i den almindelige samfundsdebat og jævnligt figurer i dagspressens overskrifter, så er stress fortsat vagt defineret. Heller ikke i den akademiske litteratur, hvor begrebet også har vundet stor udbredelse, hersker der enighed om, hvad terminologien dækker over.

Vi vil i det følgende gennemgå, hvordan stress som begreb har udviklet sig siden de første fysiologiske undersøgelser i 1930'erne. Gennemgangen er bygget på et videnssociologisk studie omkring Hans Selyes rolle i udarbejdelsen af teorien om stress (Viner 1999). Den suppleres med eksempler fra bogen: Work stress. The making of a modern epidemic (Wainwright \& Calnan 2002). Når der i det følgende ikke er angivet andre kilder, er gennemgangen baseret på Viners studie. Den videnssociologiske forståelse bygger i særdeleshed på aktør-netværksteori (ANT) (Latour 1984; 1987).

\section{Selyes oprindelige stressforståelse}

'Stress' som begreb blev italesat af Selye i 1930 'erne. Inden da havde psykologer anvendt ordet stress til at beskrive de mentale belastninger, mennesker kunne blive udsat for, og ikke som organismens reaktion. Derudover havde ikke-reduktionistiske forskere anvendt ordet stress til at betegne generelle miljømæssige belastninger af det kropslige system som modvægt til datidens stærke fokus på bakterier som årsag til al sygdom. Selye forsøgte at definere stressbegrebet som en generel, ikke-specifik fysiologisk reaktion, som gælder for alle organismer fra celleplan til dyr og mennesker. Dvs. de udvikler samme symptomer, uafhængigt af om de bliver udsat for støj, mobning eller skadelig stråling. Han baserede sin definition på deskriptive studier af ensartede defekter i forskellige pattedyrs organer, som han mente kunne henføres til et 'Generelt Adaptions Syndrom' (GAS), der var forårsaget af overbelastning fra omgivelserne. 
Dvs. fra at have været en karakteristik ved omverdenen i forhold til mennesket, blev stress karakteriseret som den tilstand som en organisme saettes $i$ ved overbelastning og de tilhørende kropslige følgevirkninger.

Selye mente, at tilstanden bestod af en samling af fysiologiske processer i organismen. Han havde dog vanskeligt ved at bevise og overbevise samtidens biologer og fysiologer om dette. Selyes forsøg på at beskrive stress som en del af en altomfattende teori, der så alt liv som en serie af adaptive reaktioner på sub-cellulært niveau, var det som skabte størst modstand. Den primære forskning og skrivning omkring emnet indtil 1950 'erne var begrænset til Walter Canons arbejde om følelsesmæssig stress og til miljøet omkring Selyes forskningsinstitut på University of Montreal (Wainwright \& Calnan 2002). Her uddannedes en del internationale studerende, som senere igangsatte stressforskning i andre lande - herunder Lennart Levi, som grundlagde stressinstituttet i Stockholm.

\section{Konstitueringen af stress gennem alliancer}

For at konstituere stress som et videnskabeligt faktum forsøgte Selye at indgå alliancer med forskellige grupperinger. En af de grupperinger, som støttede Selye, var forskere og læger med interesse i psykosomatiske lidelser. De fandt, at stressforskning kunne give et fundament for deres påstand om, at psykiske belastninger kunne føre til somatiske lidelser. Sociale forskere var også interesserede i Selyes tese om, at stress var et resultat af en desorganiseret og syg civilisation, hvor dårlig tilpasning mellem mennesker og industrielle forhold ledte til hjerte-karsygdomme.

Det var dog først i 1950'erne, hvor militæret fik interesse i stressproblematikken, at udbredelsen af stress som alment begreb tog fart. Stress blev set som et våben, man kunne bruge mod fjenden, og stressforsk- ning som del af udviklingen af en vaccine, der kunne modvirke frygt og nedbringe tab af mandskab, som var relateret til psykiske nedbrud. Militære stressforskningsafdelinger blev i stor stil oprettet i de følgende år, og i 1970'erne var en tredjedel af de amerikanske stressforskere tilknyttet militære institutioner (Wainwright \& Calnan 2002).

På samme tid fik praktiserende læger også interesse for begrebet via Selyes offentlige forelæsninger og populære bøger som for eksempel The story of the adaptation syndrome fra 1952 og The stress of life fra 1956. Interessen kom i forbindelse med forebyggelse af hjerte-karsygdomme og reumatiske symptomer, men også gennem løftet om den glæde og det gode helbred, som kan opnås gennem succesfuld tilpasning til industrisamfundets præmisser.

"Hemmeligheden bag helbred og lyksalighed ligger $i$ succesfuld tilpasning til de konstant foranderlige betingelser på vores klode; straffen for at fejle i denne store tilpasningsproces er sygdom og ulyksalighed." (Selye citeret i Viner 1999, 400, vores oversættelse).

Selye allierede sig også med datidens kapitalistiske, industrielle kræfter. Han argumenterede for nødvendigheden af at arbejde ud fra de biologiske krav, som er forbundet med adaptionssyndromet.

"Vi er nødt til at acceptere det videnskabeligt etablerede faktum, at mennesket ikke kan flygte fra sin naturlige trang til at arbejde egoistisk for at kunne gemme ting som styrker homeostasen i forhold til de uforudsigelige situationer, som livet kan konfrontere mennesket med." (Selye citeret i Viner 1999, 401, vores oversættelse).

Ifølge Selye er mennesket altså nødt til at arbejde, og arbejdet er den bedste garant mod revolutionære, destruktive tendenser. 
At stress fik en negativ betydning, mente Selye skyldes sjusk med ordet 'distress' (Selye 1974). Stressforskningen lovede desuden øget produktivitet hos arbejderne, når de blev bedre til at adaptere til samfundets krav. Begrebssætningen af positiv eustress kan forstås i lyset af denne indfortolkning af stress i industrisamfundets arbejdsmoral:

"Det er en biologisk lov, at mennesket - ligesom de lavere dyr - må koempe for de goder, som han finder voerdifulde. Vi skal bruge vores indbyggede kapacitet til at nyde eustress under udførelsen." (Selye i Viner 1999, 401 , vores oversættelse).

Heri ses også kimen til den del af stressforskningen, der betragter stress som et vilkår $\mathrm{i}$ det moderne samfund, som mennesket skal lære at tackle, for eksempel via coping (Lazarus \& Folkman 1987).

\section{Stress som hverdagsbegreb}

I løbet af 1960'erne ændrede stressbegrebet sig fra at være noget, som nogle få forskere fortalte befolkningen om, til at være et alment fænomen, som almindelige mennesker kunne fortælle forskerne om. Der blev iværksat større spørgeskemabaserede forskningsundersøgelser, der kunne associere folks oplevelse af stress med sygdomme. I 1970'erne blev stress det mest diskuterede medicinske område i det amerikanske politiske system. Stressbegrebet bredte sig i denne periode til mange forskellige biologiske fænomener, og i begyndelsen af 1980'erne begyndte stressbegrebet at blive kritiseret for at være overgeneraliseret $i$ en sådan grad, at det ikke længere var meningsfyldt at benytte. En kritik som er blevet gentaget mange gange siden (Wainwright \& Calnan 2002). Der blev igangsat ny fysiologisk forskning for at afklare de konkrete mekanismer bag stress. Forskellige former for fysiologiske reaktioner er blevet undersøgt, og flere af Se- lyes oprindelige beskrivelser er blevet afvist. Definitionen af stress som en ikke-specifikt organisk reaktion på krav i omgivelserne er stadig udbredt (Viner 1999).

Det er interessant at observere, hvordan menneskets biologiske mekanismer såsom hormonerne er blevet mobiliseret for at kæmpe under arbejdskampens eller (ledelses-) ideologiernes faner. At de kan indgå på begge sider, skyldes formentlig usikkerheden om og dobbeltheden i, hvordan de materielle manifestationer skal oversættes til observerbar adfærd og symptomer (Wainwright \& Calnan 2002). Paratheds-hormonerne cortisol og adrenalin bliver både fortolket som essentielle for at yde en god arbejdsindsats, og som ødelæggende for arbejderen. En kampplads i den forbindelse har været diskussion af 'dosis-respons' og niveauer. En anden har været et forsøg på yderligere detaljering, $\mathrm{fx}$ har forskere forsøgt at tillægge hormonet cortisol det primære ansvar for ulyst i forbindelse med lav indflydelse og dermed for stress, mens adrenalin forbindes med anspændthed (Frankenhaeuser 1981). Cortisol kan dermed forstås som hovedskurken i stressreaktionen, mens adrenalin kun er medskyldig.

Over en periode på 50 år blev stress altså forvandlet fra observationer af og vævsprøver fra rotter til et alment accepteret fænomen, der kan beskrive alt fra fysiologisk cellestress til et følelsesmæssigt hverdagsfænomen, som bliver en normal del af folks livsfortællinger (Bloch 2001). EU har forsøgt sig med en samlet definition af stress som

"de følelsesmoessige, kognitive, adfoerdsmoessige og fysiologiske rektioner på frastødende ('aversive') og farlige ('noxious') aspekter af arbejdet, arbejdets omgivelser og arbejdsorganiseringen. Det er en tilstand karakteriseret ved høj anspoendthed ('arousal') og bekymring ('distress') og ofte folelsen af ikke at kunne håndtere situationen ('coping')" 
(European Commisions 2001, 3, vores oversættelse).

Det er interessant, at definitionen spænder over flere forskningstraditioner, som er vanskeligt forenelige: Belastningsparadigmet, copingparadigmet, personlighedsparadigmet og det psykofysiologiske paradigme - se for eksempel Kristensens kronik i dette nummer af Tidsskrift for Arbejdsliv (Kristensen 2007).

En af Viners grundlæggende pointer er, at stress hverken blev udbredt, fordi der er videnskabelige fakta, der understøtter stress definitionen, eller fordi stressforskningen frembragte overbevisende behandlingsmetoder. I modsætning til Pasteurs vaccine blev der ikke fundet én stærk fysiologisk/biologisk model, som alle brugere af stressbegrebet er nødt til at forholde sig til. Stress blev et faktum, fordi det blev indoptaget i den brede, populære sundhedsforståelse, og fordi begrebet kunne indoptage mange forskellige interesser (militære, sundhedsmæssige, samfundsøkonomiske, samfundskritiske, psykosomatisk forskning, alternativ behandling med mere). Med videnssociologiske termer kan man sige, at stress blev et 'obligatory passage point' (Callon 1986). Det vil sige, at stress er blevet uomgængeligt, når man forholder sig til belastninger i arbejdet, men det er ikke på grund af en nødvendig kobling til blodprøver, laboratorieudstyr og medicin, men fordi det kan indgå i mange forskellige netværker på grund af den fortolkningsmæssige fleksibilitet.

\section{Krav-kontrolmodellen og vidensarbejderne}

Vi vil nu rette vores fokus mod Karaseks såkaldte krav-kontrolmodel. Baggrunden for at vi vælger dette nedslag her, er at Karaseks model igennem de seneste årtier stort set har været dominerende i stressdiskussionen
- specielt den skandinaviske (Bason m.fl. 2003; Belkic m.fl. 2004; Doef \& Stan 1999; Kristensen 1996; Netterstrøm \& Kristensen 2006; Wainwright \& Calnan 2002). Modellen har dermed fået karakter af at være et 'obligatory passage point' for store dele af den jobrelaterede stressdiskussion. Men ligesom stressbegrebet anser vi krav-kontrolmodellen som en del af en fortløbende (re)konstruktionsproces. Vi vil her forsøge at bidrage til denne proces, fordi modellen tilsyneladende ekskluderer vidensarbejderne fra gruppen af alvorligt truede stressmedarbejdere, samtidig med at stress artikuleres som et alvorligt problem af vidensarbejdernes interesseorganisationer.

\section{Dimensionerne i krav-kontrolmodellen}

Kendskabet til Karaseks krav-kontrolmodel er så udbredt inden for arbejdslivskredse, at de fleste læsere næppe behøver en yderligere præsentation. Vi vil alligevel bruge lidt plads på en gennemgang af modellen, fordi vi efterfølgende vil diskutere modellens kontroldimension mere indgående.

Figur 1. Karaseks krav-kontrolmodel ('job strain'). (Kristensen 2006, 162)

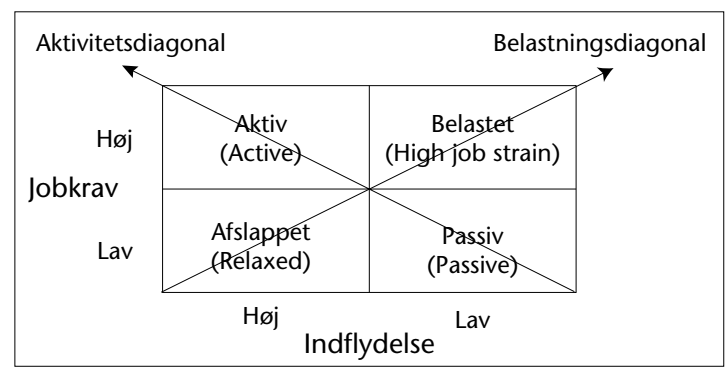

Krav-kontrolmodellen blev udviklet på basis af nationale survey data fra USA (Quality of Employment Survey) og fra Sverige (Levnadsnivåundersökningen). Undersøgelserne består af selvrapporterede data fra medarbejdere. Undersøgelserne er baseret på stratificerede stikprøver, som dækker 
bredt over alle jobkategorier-nogle jobfunktioner er dog kun svagt repræsenteret. Modellen viser, at hvis medarbejdernes indikatorer for psykologisk belastning ('strain') afbildes i forhold til to dimensioner - krav og kontrol - vil samme niveau af krav belaste mindre, jo mere indflydelse medarbejderne har på deres arbejdssituation. Modellen opdeler jobs i fire kategorier: Aktiv, passiv, belastet og afslappet. En væsentlig pointe er, at medarbejdere i de belastende job møder samme høje krav som medarbejdere i aktive job, men på grund af den lave indflydelse har de langt flere symptomer på overbelastning. Baseret på et arbejde af Johnson er social støtte blevet indarbejdet $\mathrm{i}$ modellen (Johnson \& Hall 1988). Virkningen af social støtte svarer til virkningen af indflydelse. Ved samme niveau af krav vil medarbejderne opleve en større belastning, hvis de ikke får social støtte på arbejdet.

På tværaksen (belastningsdiagonalen) fra afslappede job til belastende job svarer belastningskurven til Selyes U-kurve, som illustrer, at både høje og lave krav påvirker homeostasen negativt og dermed er stressende. Karasek og Theorell pointerer, at Selye ikke er i stand til at redegøre for, hvad en optimal stressbelastning i givet fald er (Karasek \& Theorell 1990). Det fremhæves, at ved at tilføje indflydelsesdimensionen, bliver det muligt at angive betingelser for, hvornår høje krav virker udviklende (eustress), og hvornår de virker belastende (distress). Ifølge forfatterne kan der påvises sammenhæng mellem højt belastende job og risikoen for hjerte-karsygdomme. Forfatterne argumenterer derudover for, at krav-kontrolmodellen korresponderer med modeller, der viser, at det er kombinationen af højt spændingsniveau og ulyst som primært giver stress (Frankenhaeuser 1981; Kristensen 2006; Warr 1994).
Kontroldimensionen omtales mere præcist som 'jobdecision latitude' (jobbeslutningsspillerum). Den er defineret som

"det arbejdende individs potentielle kontrol
over sine opgaver og sine handlinger i løbet
af arbejdsdagen" (Karasek 1979, 290).

Dimensionen opdeles i 'decision authority' (beslutningsautoritet, oftest oversat til indflydelse) og 'skill discretion' (færdighedsdiskretion, oftest oversat til udviklingsmuligheder). Disse dimensioner måles i den amerikanske undersøgelse som vist i tabel 1. Den svenske undersøgelse har i sin oprindelige udgave langt færre spørgsmål for hver af dimensionerne. Indflydelse fokuserer på, om den enkelte har frihed til at tage sine egne beslutninger, om medarbejderen kan vælge, hvordan arbejdet udføres, om medarbejderen har meget at sige på arbejdet, og om man deltager i beslutninger, som vedrører en selv. Udviklingsmuligheder fokuserer på, om jobbet er ensidigt gentaget eller om der er variation i arbejdet, om medarbejderens færdigheder udnyttes, om jobbet kræver et højt niveau af færdigheder, og om der er mulighed for at udvikle sine færdigheder. Det nævnes, at de to elementer af kontroldimensionen kan være uafhængige, men at empiriske resultater er ifølge forfatterne så tæt korrelerede, at de bør behandles sammen. Det nævnes desuden, at udviklingen af færdigheder er det, som muliggør, at medarbejderne får kontrol over arbejdsprocessen, men at friheden fra rigide begrænsninger har større betydning for psykologisk velbefindende end muligheden for at bruge sine færdigheder (Karasek \& Theorell 1990, 60). Kravdimensionen er baseret på spørgsmål om, hvorvidt medarbejderen skal arbejde hurtigt og hårdt, om der er tid til at udføre arbejdet, om der er modstridende krav, og om der er overarbejde. Spørgsmålet 
Tabel 1. Beskrivelse af de originale spørgsmål bag dimensionerne i krav-kontrolmodellen. Oversaettelser til dansk findes i teksten. (Karasek \& Theorell 1990)

\begin{tabular}{|l|l|l|}
\hline \multicolumn{2}{|c|}{ Decision latitude } & \multicolumn{1}{c|}{ Psychological job demands } \\
\hline \multicolumn{1}{|c|}{ Skill discretion } & \multicolumn{1}{c|}{ Decision authority } & \multicolumn{1}{c|}{ Job demands } \\
\hline Keep learning new things & $\begin{array}{l}\text { Have freedom to make my own } \\
\text { decision }\end{array}$ & Work fast \\
\hline Can develop skills & Can choose how to perform work & Work hard \\
\hline Requires high level of skill & Have a lot to say on the job & Have time to do work (-) \\
\hline Job has variety & Take part in decisions that affects me & No conflicting demands (-) \\
\hline Job requires creativity & & No excessive work (-) \\
\hline Repetitious jobs (-) & & \\
\hline
\end{tabular}

om "at arbejde hårdt" kan misforstås som et spørgsmål om fysisk hårdt arbejde.

\section{Vidensarbejdernes placering $\mathbf{i}$ modellen}

Hvis den type vidensarbejde, som vi diskuterer i denne artikel, placeres i forhold til de to jobdimensioner, vil vidensarbejderne med meget stor sandsynlighed blive placeret i den aktive kvadrant i modellen. Udviklingsmulighederne vil være høje, da jobbene er varierede, kræver kreativitet, og der er krav om at lære nyt. Indflydelse vil formodentlig også ligge højt, da den især handler om indflydelse på det daglige arbejde. Krav vil ligeledes ligge højt, idet vidensarbejderne skal arbejde hurtigt, og der typisk er modstridende krav, overarbejde, og ikke nok tid til at nå alle opgaver. Dette bekræftes da også af empirien bag krav-kontrolmodellen. I et afsnit om nye jobdesign-strategier opdeles de undersøgte job i ni typiske kategorier: Ledere, professionelle, håndværkere, teknikere/administratorer, bureaukratiseret servicearbejde, kommercielt servicearbejde, rutinepræget arbejde, fysisk prægede arbejde og marginaliserede arbejde (Karasek \& Theorell 1990, 278). Den type vidensarbejde, som vi diskuterer her, falder ind under professionelle, som for eksempel arkitekter, ingeniører, gymnasielærere og forskere. Empirien viser, at professionelle er den gruppe, som scorer højest på jobbeslutningsspillerum - højere end ledere. Samtidig scorer de lavt på fysiske krav og middel på psykiske krav og social støtte. Det vil sige, at i Karasek \& Theorels empiri har de professionelle moderat social støtte og ligger i den aktive del af krav-kontrolmodellen.

Det betyder, at der ud fra den oprindelig teoris præmisser ikke skulle være nogen grund til at forvente, at vidensarbejdere skulle være specielt stressede. Fagforeningernes påstande om øget stress hos højtuddannede vidensarbejdere efterlader dermed et paradoks. Betyder det, at stressrapporterne som ligger til grund for fagforeningernes påstande er forkerte? At krav-kontrolmodellen er forkert? At vidensarbejdet har ændret karakter, siden modellen blev udfærdiget (eksempelvis kravenes omfang og karakter)? At diskursen om vidensarbejdets karakter af høj indflydelse er misvisende og internaliseret i en sådan grad, at vidensarbejderne svarer for positivt, når de rapporterer om egen indflydelse? Eller at vidensarbejderne i virkeligheden slet ikke er stressede?

Vidensarbejdet kan meget vel have skiftet karakter, siden krav-kontrolmodellen blev udviklet. Dels ved at være mere rutinepræget 
og dels ved at være mere intensiveret. Således er funktionærer på offentlige arbejdspladser for eksempel kommet under meget større pres, end den oprindelige empiri bag modellen antyder, og meget vidensarbejde er standardiseret (Karasek \& Theorell 1990; Nielsen $\&$ Andersen 2004). Men undersøgelser af det psykiske arbejdsmiljø fra NFA bekræfter placeringen af professionelle job som aktive job. Akademikere, ingeniører og arkitekter og fuldmægtige (og chefer) ligger signifikant højere end det nationale gennemsnit i forhold til kvalitative og kvantitative krav. Samme grupper (på nær naturvidenskabelige akademikere) ligger middelhøjt til højt på indflydelse (chefer ligger helt $\mathrm{i}$ toppen) og højt på udvikling og variation. Det vil sige, at der ikke er tvivl om, at disse grupper falder ind under aktive job. Grupperne ligger middel på social støtte. Interessant nok ligger grupperne også på middelniveau på stressskalaen, hvilket kunne forventes ud fra modellen, idet de aktive job ikke er uden stress på grund af de høje krav (NFA 2006). Det vil sige, at NFA's tal ikke bekræfter fagforeningernes alarmerende påstande om særlig høj stress for vidensarbejdere.

Det er meget sandsynligt, at vidensarbejdere overvurderer den indflydelse, de har på deres egen arbejdssituation. Når arbejdet individualiseres, og medarbejderne bliver selvledede, får de typisk frie tøjler i forhold til hvor, hvornår og hvordan de vil arbejde (Allvin m.fl. 2006). De får ofte også indflydelse på valg af opgaver, fx gennem deltagelse i udbudsprojekter. Ved at påloegge medarbejderen ansvar og frihed til at være medskaber af egen livs- og arbejdssituation, kan lederne i et vist omfang fralægge sig ansvaret for medarbejderens trivsel, hvis medarbejderen internaliserer både ansvaret for indflydelse og krav (Tynell 2001). At det dermed bliver vanskeligt at sætte grænsen, kan ses af følgende typiske medarbejderud- talelser, som kommer fra et nyligt afsluttet ph.d.-projekt om vidensarbejde:

"Det kroever en stor grad af selvdisciplin, for man kan let blive suget ned $i$ arbejdet - hvor det overtager ens liv" og "du er nødt til selv at traekke en streg i sandet ellers aeder jobbet dig $o p^{\prime \prime}$ (Ipsen 2007).

Begge disse udsagn peger i retning af, at vidensarbejderne internaliserer ansvaret for både krav og kontrol og betragter begge dele som individuelle anliggender.

\section{Betydningen af indflydelse}

Denne diskussion giver anledning til at indføre en skelnen mellem indflydelse $i$ og indflydelse over arbejdet (Aronsson 1991). Denne skelnen er vigtig, fordi krav-kontrolmodellen primært opererer med indflydelse $i$ arbejdet. Det nævnes i beskrivelsen af modellen, at indflydelse over arbejdet også er vigtig, men at dette primært går gennem den kollektive repræsentation (Aronsson 1991; Karasek \& Theorell 1990). Mange vidensarbejdere ser deres arbejde som individuelt styret og benytter derfor ikke så ofte kollektiv repræsentation til at få indflydelse over fx arbejdsbelastningen (for eksempel faktureringsgraden eller mængden af projekter), som mere klassiske lønarbejdergrupper gør (Andersen \& Rasmussen 2005; Ipsen 2007). Denne problematik ændrer imidlertid ikke ved, at krav-kontrolmodellen i sin oprindelige udformning ikke baserer sig på indflydelse over arbejdet, men på medarbejdernes subjektive opfattelse af indflydelse $i$ arbejdet (herunder variation, brug og udvikling af evner). Den høje indflydelse, som vidensarbejderne rapporterer i NFA's spørgeskemaundersøgelse, vedrører deres indflydelse $i$ arbejdet, men der er grund til at tro, at de overvurderer deres egen indflydelse over arbejdet (Ipsen 2007). 
Dermed er paradokset stadigvæk aktuelt, og krav-kontrolmodellen kan ud fra denne betragtning kun dække vidensarbejdernes problemer ved at refortolke indflydelsesdimensionen, så den inddrager indflydelse over arbejdet som en væsentlig del af jobbeslutningsspillerummet. Dette ville imidlertid være i konflikt med modellens oprindelige empiriske grundlag. Det ville føre til det problem, at der ville være meget lille spredning i modellen. Få jobgrupper, specielt industriarbejdsgrupper, men også vidensarbejdergrupper, ville kunne placeres $\mathrm{i}$ den aktive jobkategori, og dermed ville der være for få observationer.

Det er imidlertid ikke ualmindeligt, at dimensionerne og udfaldsvariablene i kravkontrolmodellen redefineres af forskere, som forsøger at eftervise modellens gyldighed. Et review af 63 undersøgelser fra 1979 til 1999 viser, at der efterprøves flere forskellige skalaer for indflydelse, krav og støtte i forhold til forskellige indikatorer på psykisk overbelastning. Undersøgelserne afprøves desuden i forhold til forskellige jobkategorier. Det konkluderes i reviewet, at der er meget svingende støtte til modellen, og at den største støtte opnås, når målene for indflydelse er relateret til de krav, medarbejderne er udsat for (Doef \& Stan 1999). Læses reviewet ud fra et vidensarbejderperspektiv, er det bemærkelsesværdigt, at flertallet af studier, som fokuserer empirien på funktionærgrupper, ikke støtter modellen (10 i forhold til 3). Et andet interessant perspektiv er, at flere af undersøgelserne viser, at høje krav i arbejdet ikke kan modificeres af øget indflydelse. Det har den konsekvens, at hvis vidensarbejdet er kendetegnet ved potentielt uendelige krav, så er denne type arbejde måske helt uden for krav-kontrolmodellens gyldighedsområde. Derfor er det næppe indflydelse $i$ arbejdet men indflydelse over moengden af krav $i$ arbejdet, som er mest væsentligt for forebyggelse af stress i vidensarbejdet.

\section{Interesser bag krav-kontrolmodellen}

Ligesom det blev demonstreret for stressbegrebet generelt, så er der er ingen tvivl om, at krav-kontrolmodellen er indskrevet i forskellige interesser. Men i modsætning til det generelle stressbegreb, så er krav-kontrolmodellen knyttet tættere sammen med en specifik interesse - det socialdemokratiske projekt om forøgelse af medarbejderindflydelse og udvikling i industriarbejde (Wainwright \& Calnan 2002). Det bygger specielt på Gardells arbejde vedrørende vigtigheden af medarbejderindflydelse (Aronsson 1991). Der skrives direkte i indledningen til Karasek og Theorells bog, at den er

"et politisk bevidst forsøg på at fjerne de residuale destruktive aspekter af moderne industrialisering med videnskabelige evidens om problemer og videnskabeligt formulerede løsninger" (Karasek \& Theorell 1990, 3, vores oversættelse).

Ved at fokusere på arbejdets udformning flyttes ansvaret for stress fra individet og fra specifikke omgivelsesfaktorer til organisatorisk design baseret på indflydelse og udvikling. De sidste kapitler i bogen gennemgår mulige jobdesign-strategier, som forhindrer, at job bliver indholdstomme og ensidigt gentagne. Visionerne kobles til Piore og Sabels arbejde omkring industrielle distrikter og et nyt industrielt brud, hvor der åbnes for et opgør med taylorismens og automatiseringens negative tendenser - for industriarbejderne vel at mærke. Visionerne omhandler primært job, som traditionelt set har lav indflydelse i arbejdet. Og der argumenteres for, at det er et vigtigt demokratisk projekt, fordi forfatterne kan henvise til empiri, som viser, at arbejdere i job med lav indflydelse på længere sigt udvikler mindre politisk engagement, hvorimod arbejdere $i$ aktive job engagerer sig mere aktivt $i$ ar- 
bejdspladsdemokratiet (og samfundsdemokratiet) (Karasek \& Theorell 1990).

\section{Afsluttende diskussion}

Formålet med denne artikel har ikke været at definere et nyt stressbegreb eller at argumentere for at vidensarbejdere er mere stressede end andre faggrupper. Vi har i artiklen forsøgt at demonstrere, hvordan stressbegrebet (og betegnelsen vidensarbejde) er under en stadig (re)konstruktion. Det er ikke blot et objektivt akademisk definitionsarbejde, men derimod en proces der afspejler forskellige samfundsmæssige traditioner, miljøer og interesser. Artiklen peger på, at forskellige aktører i samfundsdebatten forsøger at få stressbegrebet defineret på en måde, som fremhæver bestemte metoder og løsningsmodeller. Derigennem kommer stressbegrebet til at inkludere særlige jobkategorier og grupper og til at ekskludere andre grupper. Men i modsætning til stressbegrebet kan krav-kontrolmodellen ikke nemt genfortolkes og modificeres, således at den understøtter vidensarbejdernes interesser - modellen fremstår nærmere som en hindring for troværdigheden af de akademiske fagforeningers undersøgelser. På den måde bliver krav-kontrolmodellen et element $\mathrm{i}$ 'the quiet politics of categorical work' (Bowker \& Star 1999) og illustrerer det forhold, at kategorier, standarder og klassifikationssystemer på en gennemgribende - men ofte meget diskret - måde er med til forme og præge vores samfund; i dette tilfælde ved at ekskludere vidensarbejdere fra stressproblematikken.

\section{Misvisende aktivitetsdiagonal}

For eksempel skaber aktivitetsdiagonalen i krav-kontrolmodellen et misvisende billede af de empiriske resultater, som ligger til grund for modellen. Pilen mod aktive job angiver, at jo mere aktivt et job er (højere krav og indflydelse), desto bedre er jobbet.
Dermed antydes det implicit, at risikoen for at udvikle stress bliver mindre. Men ser man på, hvor stor risikoen er for at blive stresset i det aktive område, så er den højere end i det afslappede område, hvor indflydelse er høj og kravene lave. Og bevæger man sig imod højere krav, så vil risikoen for at få stress stige. At modellen er udformet som den er, kan ses som et kompromis mellem samfundsmæssige kræfter, som ønsker produktiviteten forøget, og kræfter som kæmper for øget sundhed (og demokratisk indflydelse). Kompromisset indebærer, at et vist niveau af stress er uundgåeligt og acceptabelt. Problemet ved modellen er, at dette kompromis udvisker, at stor indflydelse og store krav giver stress, og at det bliver værre, når man bevæger sig mod meget store krav og stor indflydelse. At dette ikke italesættes skyldes, at det ikke var et aktuelt problem for de medarbejdergrupper med lav indflydelse, hvis interesser modellen blev udviklet for at støtte. Men det skyldes formodentlig også, at ledere og professionelle blev opfattet som privilegerede grupper, der ikke havde brug for alternative jobdesign.

Set i lyset af ovenstående må man overveje, om man bør gribe til andre forklaringsmodeller end krav-kontrolmodellen, hvis man ønsker at tjene vidensarbejdernes interesser. Specielt hvis der er hold i den alvorlige stressproblematik, som fagforeningernes undersøgelser 'dokumenterer'. Flere forskere foreslår som nævnt, at vidensarbejdernes stressproblemer fortrinsvis er forbundet med grænseløshed, uendelige krav og uforudsigelighed, mens industriarbejdets stressorer især er kombinationen af højt tempo og lav indflydelse - se tabel 2 (Allvin m.fl. 2006; Bason m.fl. 2003). Det underforstås i denne oversigt, at den grundlæggende fysiologiske stressreaktion er den samme.

Opdelingen i klassiske, nyklassiske og moderne stressproblemer åbner op for, at kravkontrolmodellen kun er relevant for de 
Tabel 2. Typer af stressproblemer. (Bason m.fl. 2003)

\begin{tabular}{l|l|l|l}
\hline & $\begin{array}{l}\text { Klassiske } \\
\text { stressproblemer }\end{array}$ & $\begin{array}{l}\text { Nyklassiske } \\
\text { stressproblemer }\end{array}$ & $\begin{array}{l}\text { Moderne } \\
\text { stressproblemer }\end{array}$ \\
\hline Type af arbejde & Industriarbejde & Omsorgsarbejde & Videnarbejde \\
\hline Stressorer & $\begin{array}{l}\text { Ensformighed } \\
\text { Højt tempo } \\
\text { Lav indflydelse }\end{array}$ & $\begin{array}{l}\text { Høj belastning } \\
\text { Følelsesmæssige krav } \\
\text { Konflikter }\end{array}$ & $\begin{array}{l}\text { Grænseløshed } \\
\text { Uendelige krav } \\
\text { Uforudsigelighed }\end{array}$ \\
\hline $\begin{array}{l}\text { Typiske } \\
\text { jobfunktioner }\end{array}$ & $\begin{array}{l}\text { Kasseassistenter } \\
\text { Ufaglærte industriarbejdere }\end{array}$ & $\begin{array}{l}\text { Sygeplejersker } \\
\text { Lærere } \\
\text { SOSU-assistenter }\end{array}$ & $\begin{array}{l}\text { It-medarbejdere } \\
\text { Reklamefolk } \\
\text { Embedsmænd i offentlig sektor }\end{array}$ \\
\hline
\end{tabular}

klassiske stressproblemer. Vi ser to dilemmaer forbundet med at forkaste krav-kontrolmodellen for de to andre områder. Et dilemma er, at krav-kontrolmodellen har et relevant og tydeligt budskab om vigtigheden af indflydelse og social støtte (hvilket formodentlig også er grunden til, at den har overlevet på trods af blandet videnskabelig støtte). Indflydelse og social støtte som kriterier for jobdesign er også relevante for vidensarbejdere - selv om de ikke nødvendigvis er så vigtige i forhold til forebyggelse af stress.

\section{Er alternativerne værre?}

Det andet dilemma er, at der kun er få andre stressrelaterede alternative jobdesign. Det betyder, at der bliver fri bane for den individuelle coping-tradition (Lazarus 1993; Lazarus \& Folkman 1987), med alle denne traditions symptombehandlende tilbud i form af udviklingssamtaler, coaching, terapi, meditation, stressklinikker, stressombudsmænd og lignende (se for eksempel Dalsgaard 2006; Ipsen 2007). Disse tilbud bæres igennem af en stort skare af interessenter i form af terapeuter, læger, konsulenter, HRM-afdelinger med flere (Wainwright \& Calnan 2002). Problemet er, at disse tilgange risikerer at gøre stress problematikken til et individuelt anliggende, hvilket adskillige forskere har påpeget risikerer at forøge stressproblemerne på grund af den tætte kobling til identitet og karriere, se for eksempel (Bovbjerg 2003; Tynell 2001; Wainwright \& Calnan 2002). Et andet alternativ er Siegrist 'Efford-RewardImbalance'-model, som også individualiserer problematikken, men dog har større fokus på jobdesign (Siegrist 1996).

Men det behøver ikke nødvendigvis at være enten/eller, selv om de forskellige forskningsparadigmer kun sjældent refererer til hinanden. Dels findes der copingvarianter, som også fokuserer på organisatorisk coping (Aldwin 1994), dels kan krav-kontrol-, 'efford-reward'- og copingtilgangene supplere hinanden. Teorien bag krav-kontrolmodellen inddrager en form for coping element ved at inkorporere et læringselement (Karasek \& Theorell 1990, 99). Læringspointen er, at medarbejdere i job med høj belastning akkumulerer belastninger, hvilket fører til nervøsitet/angst, som bliver en forhindring for læring og dermed forhindrer en forøget håndtering af belastningerne. Derimod vil aktive job føre til en læringsproces, som akkumulerer følelsen af mestring og dermed forhindrer, at belastninger ophobes. Denne konstruktion inddrager altså den enkelte medarbejders evne til at mestre stress, men gør denne evne til en effekt af jobsituationen frem for et karakteristika ved individet. Denne konstruktion indebærer også, at muligheden for at høje krav og høj indflydelse fører til aktiv læring er størst, når "udfordringerne $i$ situationen er matchet med individets kontrol over alternativer eller evner..." (Karasek \& Theorell 1990, 92, vores oversættelse). 
Problemet med krav-kontrolmodellens læringselement i forhold til vidensarbejde er, at det er knyttet så snævert sammen med indflydelsesproblematikken. Hvis fundamentet for udviklingen af stress hos vidensarbejderne ikke er manglende indflydelse, men uforudsigelighed og uendelige krav, så fungerer modellens forslag ikke i forhold vidensarbejdet - eller for omsorgsarbejdet i øvrigt, som er kendetegnet ved konflikter og høje følelsesmæssige krav (Bason m.fl. 2003).

\section{Bør modellen redesignes?}

Hvis modellen ikke skal forkastes, så må det overvejes, om den bør re-designes i forhold til vidensarbejdet, set i lyset af, at forslagene til jobdesign ikke er relevante, og fordi modellen diskvalificerer diskussioner om, at vidensarbejdere kan udvikle stress i alvorlig grad. Der findes allerede hos Karasek \& Theorell argumenter for, at det er nødvendigt at redesigne modellen ved meget høje niveauer af indflydelse.

"Der er beviser for, at ved høje niveauer af indflydelse, flader symptomerne ud eller begynder endda at vokse ved forøget indflydelse" (Karasek 1979, 304, vores oversættelse).

Tilsvarende overvejelser om, at for høje niveauer af indflydelse kan være belastende, findes i vitaminmodellen (Warr 1994). Disse argumenter peger på, at ved høje niveauer af krav og indflydelse bliver en balancegang mellem krav og kontrol meget vanskelig.

"Job redesign-strategier, som forsøger at reducere belastning i allerede komfortable job, kan nå et punkt, hvor udbyttet formindskes og faktisk skaber problemer" (Karasek 1979, 304, vores oversættelse).

Denne konklusion er yderst relevant for vidensarbejdere. Hvis medarbejderne overbe- lastes ved både meget høje niveauer af krav og af indflydelse - uafhængig af den anden dimension, eller måske snarere fordi de to dimensioner smelter sammen - så er det et stort problem, at modellen antyder, at hvis blot krav og kontrol følges ad, bliver arbejdet mere udviklende og mindre belastende.

Et væsentligt problem ved et redesign af modellen er, at det er problematisk og vanskeligt forståeligt at redefinere kontroldimensionen (vidensarbejderne har i virkeligheden ikke den rigtige indflydelse) - dels fordi det vil være vanskeligt at formidle, dels fordi det vil kræve et helt nyt empirisk grundlag, hvis den reviderede model skulle have støtte i videnskabelige empiriske studier (da de eksisterende data jo placerer vidensarbejde $\mathrm{i}$ den aktive jobkategori). Derudover ville modellens indflydelsesperspektiv formodentlig komme i konflikt med arbejdsgivernes forståelse af ledelsesretten, hvilket kunne forhindre en bred accept. Skal modellen redesignes, er det nødvendigt at den tager højde for den tætte sammenvævning af krav, indflydelse, rolle, identitet og (selv)ledelse, som kendetegner vidensarbejdet. NFA's seks guldkorn kan opfattes som en form for opblødning, idet denne tankegang lægger op til, at belastningerne kan komme fra mange forskellige kilder. Men meget peger i retning af at NFA's model - ligesom krav-kontrolmodellen - primært er udviklet i forhold til det udviklende arbejde for industriarbejdergrupper (Kristensen \& Smith-Hansen 2003).

Vi vil ikke gå nærmere ind i diskussionen af alternative modeller for forebyggelse af stress i vidensarbejdet. Men for os at se er der er brug for en ny stressrelateret model for jobdesign, som svarer til krav-kontrolmodellen, men som kommer med andre forslag end øget indflydelse. ${ }^{1}$ Der er behov for modeller, som forholder sig forebyggende til konsekvenserne af individualiseringen og internaliseringen af høje krav og (høj) indflydelse og vigtigheden af god le- 
delse og kollektiv indflydelse. Vi vil specielt plædere for en model, som flytter fokus fra symptombehandlende indsatser til forebyggende organisatoriske indsatser.

\section{NOTER}

1. Vi deltager som forskere i projektet "Vidensarbejde og stress - mellem begejstring og belastning". Dette projekt fokuserer på at forstå stressfænomener og afprøve løsninger i rela- tion til de særlige vilkår, der gør sig gældende i vidensarbejdet. Flere oplysninger kan findes: www.videnogstress.dk

\section{ReferenCER}

Albertsen, Karen, Tage Søndergård Kristensen \& Jan Pejdersen (2007): Lange og skæve arbejdstider - kan øget indflydelse bedre balancen, i Tidsskrift for Arbejdsliv, 9, 1, 61-80.

Aldwin, Carolyn M. (1994): Stress, coping, and development: an integrative perspective, New York, Guilford Press.

Allvin, Michael m.fl. (2006): Gränslöst arbete - socialpsykologiska perspektiv på det nye arbetslivet, Ljubljana, Liber.

Andersen, Ole Steen \& Søren Barlebo Rasmussen (2005): Sådan leder du medarbejdere, der er klogere end dig selv, København, Børsens Forlag.

Aronsson, Gunnar (1991): Dimensions of control as related to work organization, stress and health, i Jeffrey V. Johnson \& Gunn Johansson The psychosocial work environment: work organization, democratization and health, New York, Baywood Publishing Company, 111-120.

Bason, Christian, Agi Csonka \& Nicolaj Ejler (2003): Arbejdets nye ansigter, København, Børsens forlag.

Belkic, Karen m.fl. (2004): Reviews - Is job strain a major source of cardiovascular disease risk? i Scandinavian Journal of Work Environment and Health, 30, 2, 85-128.

Bloch, Charlotte (2001): Flow og stress. Stemninger og følelseskultur i hverdagslivet, Frederiksberg, Samfundslitteratur.

Bovbjerg, Kirsten Marie (2003): Selvets disciplinering - en ny pagt i arbejdslivet, i Tidsskrift for Arbejdsliv, 5, 3, 41-17.
Bovbjerg, Kirsten Marie (2001): Følsomhedens etik - Tilpasning af personligheden i New Age og moderne management, Højbjerg, Hovedland.

Bowker, Geoffrey \& Susan Leigh Star (1999): Sorting Things Out. Classification and its Consequenses, Cambridge, Massachusetts, MIT Press.

Callon, Michael (1986): Elements of a sociology of translation: Domestication of the Scallops and the Fishermen of St. Brieuc Bay, i John Law (red.): Power, Action and Belief: A New Sociology of Knowledge? London, Routledge, 196-37.

Castells, Manuel (1996): The information age: economy, society and culture: The rise of the network society, Vol.1, Oxford, Blackwell Publishers.

Dalsgaard, Thomas (2006): Stress - et vilkår i det moderne arbejdsliv, København, Jurist- og Økonomforbundets Forlag.

Davenport, Thomas H. (2005): Thinking for a living. How to get better performance and results from knowledge workers. Boston, Harvard Business School Press.

DeFillippi, Robert, Michael Arthur \& Valerie Lindsay (2005): Knowledge at work: Creative collaboration in the global economy, Boston, Blackwell Publishing.

Doef, Margot van der \& Maes Stan (1999): The Job Demand-Control(-Support) Model and psychological well-being: A review of 20 years of empirical research, i Work and Stress, 13, 2, 87-114.

Drucker, Peter F. (1999): Management challenges 
for the 21st century, New York, HarperCollins.

Drucker, Peter F. (1993): Post-capitalist society, Oxford, Butterworth- Heinemann.

European Commisions (2001): Guidance on work-related stress. Spice of life or kiss of death? Belgium, European Communities.

Frankenhaeuser, Marianne (1981): Coping with Stress at Work, i International Journal of Health Services, 11, 4, 491-20.

Ipsen, Christine (2007): Vidensarbejderens saerlige arbejdssituation og muligheder for forebyggelse af arbejdsrelateret stress $i$ vidensarbejdet. $-E t$ kvalitativt studie af arbejdsrelateret stress $i$ vidensarbejdet, Danmarks Tekniske Universitet, Institut for Produktion og Ledelse.

Johnson, Jeffrey V. \& Ellen M. Hall (1988): Job Strain, Work Place Social Support, and Cardiovascular Disease: A Cross-Sectional Study of a Random Sample of the Swedish Working Population, i American Journal of Public Health, 78, 10, 1336-1342.

Karasek, Robert A. \& Töres Theorell (1990): Healthy Work - Stress, Productivity, and the Reconstruction of Working Life, New York, NY, Basic Books.

Karasek, Robert A. (1979): Job Demands, Job Decision Latitude, and Mental Strain: Implications for Job Redesign, i Administrative Science Quarterly, 24, 2, 285-308.

Karreman, Dan, Stefan Sveningsson \& Mats Alvesson (2002): The return of the machine bureaucracy? Management control in the work settings of professionals, i International Studies of Management and Organization, 32, 2, 70 .

Kelloway, E. Kevin \& Julian Barling (2000): Knowledge work as organizational behavior, i International Journal of Management Reviews, 2, 287-304.

Kristensen, Tage Søndergård (2007): Stress nok til alle? i Tidsskrift for Arbejdsliv, 9, 2, 80-85.

Kristensen, Tage Søndergård (2006): Stress og psykosomatiske sygdomme, i Lars Iversen (red.): Medicinsk Sociologi - Samfund, Sundhed og Sygdom, København, Munksgaard.

Kristensen, Tage Søndergård \& Lars Smith-Hansen (2003): Det udviklende arbejde. Helbred, stress og kvalifikationer, København, Frydenlund.

Kristensen, Tage Søndergård (1996): Job stress and cardiovascular disease: a theoretic critical reviewar disease: a theoretic critical review, i Journal of occupational health psychology, 1, 3, 246-260.

Latour, Bruno (1987): Science in action, Cambridge, Harvard University Press.

Latour, Bruno (1984): The pasteurization of France, Cambridge, Harvard University Press.

Lazarus, R. S. (1993): From psychological stress to the emotions: A history of changing outlooks, i Annual Review of Psychology, 44, 1, 1-21.

Lazarus, Richard S. \& Susan Folkman (1987): Transactional theory and research on emotions and coping, i European Journal of Personality, 1, 3, 141-169.

Leonard, Dorethy \& Walther Swap (2005): Deep Smarts. How to cultivate and transfer enduring business wisdom, Boston, Harvard Business School Press.

Netterstrøm, Bo \& Tage Søndergård Kristensen (2006): Psykisk arbejdsbelastning og iskæmisk hjertesygdom, i Ugeskrift for loeger, 167, 46, 4348-4355.

NFA (2006): Psykisk arbejdsmiljø, http://www.arbejdsmiljoforskning.dk/Nationale\%20Data/ 3DII.aspx, Nationale Forskningscenter for Arbejdsmiljø.

Nielsen, Flemming \& Vibeke Andersen (2004): Selvledelse under systemkontrol, i Vibeke Andersen, Bruno Clematide \& Steen Høyrup Arbejdspladsen som loeringsmiljø, Frederiksberg, Learning Lab Denmark, Roskilde Universitetsforlag, 53-72.

Nonaka, Ikujiro \& Hirotaka Takeuchi (1995): The knowledge-creating company, New York, Oxford University Press.

Reich, Robert B. (1992): The Work of Nations, New York, Vintage Books.

Selye, Hans (1974): Stress uden Angst, København, Gyldendal.

Sennett, Richard (2003): Respekt $i$ en verden af ulighed, København, Hovedland.

Siegrist, Johannes (1996): Adverse health effects of high-effort/low-reward conditions, i Journal of Occupational Health Psychology, 1, 1, 27-41.

Starbuck, W. H. (1992): Learning by Knowledge-Intensive Firms, i Jounal of Management Studies, 6, 29, 713-27.

Tynell, Jesper (2002): Det er min egen skyld 
- Nyliberale styringsrationaler inden for Human Ressource Management, i Tidsskrift for Arbejdsliv, 4, 2, 7-18.

Tynell, Jesper (2001): Da medarbejderne blev en ressource, Roskilde, RUC.

Viner, Russell (1999): Putting Stress in Life: Hans Selye and the Making of Stress Theory, i Social Studies of Science, 29, 3, 391-410.

Wainwright, David \& Michael Calnan (2002):

Work Stress. The Making of a Modern Epidemic, Philadelphia, Open University Press.

Warr, Peter (1994): A conceptual framework for the study of work and mental health, i Work and Stress, 8, 2, 84-97.

Ole Henning Sørensen, cand. polyt., ph.d., afspændingspædagog, er seniorforsker ved det Nationale Forskningscenter for Arbejdsmiljø (NFA).

e-mail: ohs@nrcwe.dk

Anders Buch, cand. mag., ph.d., er chefkonsultent i Ingeniørforeningen i Danmark og lektor på Institut for Produktion og Ledelse (IPL), Danmarks Tekniske Universitet.

e-mail: abu@ida.dk \& abu@ipl.dtu.dk

Peter Holdt Christensen, cand. merc., ph.d., er lektor ved Institut for Ledelse, Politik og Filosofi, Copenhagen Business School.

e-mail: holdt@cbs.dk

Vibeke Andersen, cand. techn. soc., er lektor i Ledelse, organisation og arbejdsliv ved Institut for Produktion og Ledelse, Danmarks Tekniske Universitet.

e-mail: va@ipl.dtu.dk 